\title{
Insight into the Relationship between Entrepreneurship Orientations and Performance: The Case of SME Exporters in Malaysia
}

\author{
(Mendalami Hubungan Antara Orientasi Keusahawanan dengan Prestasi: \\ Kes Pengeksport IKS di Malaysia) \\ Md Daud Ismail \\ (Faculty of Economics and Management, Universiti Kebangsaan Malaysia) \\ Azwardi Md Isa \\ (College of Laws, Government, and International Studies, Universiti Utara Malaysia) \\ Mohd Helmi Ali \\ (Faculty of Economics and Management, Universiti Kebangsaan Malaysia)
}

\section{ABSTRACT}

The rise in the number of small and medium businesses competing in foreign markets has led to growing interest among researchers in the study of the international activities of these firms. Previous studies have focused on how small businesses successfully compete in the market alongside larger and resourceful firms despite the former's scarcity of resources. In this light, we develop the conceptual framework that is based upon the resource-based view, and explore the link between firm-specific resources and export performance. This study examines the relationships between entrepreneurial dimensions, namely pro-activeness, risk-taking, and innovativeness, and the performance of the exporter. Based on a sample of 220 SMEs, this study found that pro-activeness affects export performance positively and significantly. In addition, innovativeness was found to be significantly associated with export performance. Finally, the paper ends with the conclusion, a presentation of the limitations of the study, and suggestions for future research.

Keywords: International business; entrepreneurship; export performance; resource-based view, SMEs

ABSTRAK

Peningkatan minat penyelidik ke atas kajian aktiviti antarabangsa bagi perniagaan kecil dan sederhana (PKS) berkait rapat dengan pertumbuhan jumlah firma berkenaan yang bersaing di pasaran asing. Titik rujukan kajian lepas adalah meskipun PKS menghadapi kekangan sumber namun perniagaan ini mampu bersaing dengan jayanya dalam pasaran di samping firma besar yang mempunyai sumber yang banyak. Berdasarkan pandangan ini kami membangunkan kerangka konsepsual berdasarkan kepada pandangan berasaskan sumber dan melihat kesan dimensi keusahawanan iaitu, pro-aktif, pengambilan-risiko dan inovasi ke atas pencapaian eksport. Berdasarkan sampel 220 PKS hasil kajian ini mendapati bahawa pro-aktif dengan signifikan mempengaruhi pencapaian eksport. Selain itu, inovasi juga didapati secara signifikan berhubungan dengan pencapaian eksport. Di akhir kertas ini kami membincangkan kesimpulan kajian, limitasi kajian serta cadangan kajian akan datang.

Kata kunci: Perniagaan antarabangsa; keusahawanan; prestasi eksport; pandangan berasaskan sumber; IKS

\section{INTRODUCTION}

Previous studies have analyzed various aspects of successful small and medium enterprises (SMEs) in international business (O’Cass \& Weerawardena 2009). However, the behavior of SMEs in international markets is relatively less understood compared to bigger firms, particularly those originating from emerging markets (Che Senik et al. 2012; Filatotchev et ak. 2009).Given that an international business involves resource-intensive activities, and that its intricacy requiressizeable resourcespecific investment, scholars have focused on the ability of SMEs to compete alongside large firms despite the inherent constraint of resource scarcity. Scholars disagree on the mechanism by which small businesses manage to overcome the constraint and succeed in cross border operations (Higon \& Driffield 2011). An explanation that has recently gained enormous acceptance from the international business researchcommunity is closely related to the organizational capabilities of the SMEs (e.g., Knight \& Cavusgil 2004; Lu et al. 2010; Lumpkin, Cogliser \& Schneider 2009; Woldesenbet, Ram \& Jones 2012), specifically the entrepreneurial capability posture.

The literature indicates that the study of the behavioral aspect of organizations is subject to the size and country of origin of the firm. Therefore, this study focuses on SMEs in emerging markets primarily because of the scarce research in this area, despite the growing importance of these markets in the global economy (Wright, Filatotchev \& Hoskisson 2005). Emerging market is distinct froma developed economy such that the institutional support is less developed, the domestic market is small, and the firms in the market have relatively fewer resources. This 
distinction implies that although extensive studies have been conducted in the context of developed nations, the findings from these reports cannot be generalized to the small emerging markets. Thus, this study is necessary. In addition, the emerging market offers a distinctive framework by which the theoretical and empirical understanding of the behavior of SME scan be expanded (Ali Ulubasoglu, Akdis \& Kok 2009).

To address the research gap, the present study bases on the resource-based view (RBV) to develop the theoretical foundation. The RBV accentuates firm-specific capabilities as a determinant of performance (Teece, Pisano \& Shuen 1997). This emphasis on the importance of the capabilities of the firm in literature is placed due to its role in transforming firm internal resources into superior output compared to its competitors $(\mathrm{Lu}$ et al 2010). Ultimately, resources enable the firms to offer value products to the market. Accordingly, in the current study, we view organizational capabilities as a demonstration of the firm's capacity to perform repetitive constructive tasks that relate to its ability to create value, as captured by Knight and Cavusgil (2004).

In particular, the present study examines the firmspecific capability that facilitates success in export markets. In this regard, we are more sympathetic to the observations of Knight and Cavusgil (2004) on the flexibility posture of small firms that gives rise to culturerelated capabilities. In this study,we study entrepreneurial orientation from the perspective of organizational culture, and attempt to investigate the impact of entrepreneurial orientation on export performance. We conceptualize entrepreneurial orientation as a second-order construct that consists of three sub-constructs, namely, pro-active, risk-taking, and innovative. Unlike previous studies, the present study advanced its investigation by gaining insight into the relationship by evaluating the effect of each dimension of entrepreneurship orientation on the export performance of SMEs. Hence, this study adds a new perspective to the existing literature, and enhances our understanding of the interaction between entrepreneurship orientation and export performance.

We arrange this paper as follows. In the next section, the review of related literature is presented. Subsequently, the succeeding sections are the discussions on the hypotheses, the methodology, and the results. We conclude this article with a discussion of the findings, limitations, and implications for future research.

\section{ENTREPRENEURSHIP ORIENTATION AND HYPOTHESES}

Entrepreneurial orientation (EO) has been widely analyzed in literature (Casillas et al. 2009). The pioneering work by Miller (1983) has made a significant impacton entrepreneurship research. Miller (1983: 771) refers to entrepreneurial firms as "...those that are geared towards innovation in the product market field by carrying out risky initiatives, and which are the first to develop innovations in a pro-active way in an attempt to defeat their competitors". Since the publication of this report, the concept of entrepreneurial orientation has become the focus of many researchers. One of the studies based on Miller's work that received wide attention is that of Lumpkin and Dess (1996), which has become the main reference for numerous subsequent studies. These authors investigated the nature of entrepreneurial construct, which eventually become the grounded theory of many studies. The concept of entrepreneurship orientation, which is the major contribution of this work, is suggested to be associated with the decision-making activities that managers used to act entrepreneurially and pursue new entry. Another study that used Miller's work as a conceptual foundation is that of Atuahene-Gima and Ko (2001) which advocates that entrepreneurship orientation may translate to a strong and positive focus on innovation and, consequently, an increase in competitiveness.

Avlonitis and Salavo (2007) contend that organizations can exhibit contradictory entrepreneurship orientations; that is, either defenders and prospectors. As explained by the authors, firms that are labeled defenders and reactive demonstrate a more defensive direction in taking risk and seeking opportunity, whereas firms with an opposite direction are labeled as prospectors, proactive, and entrepreneurial firms. To differentiate, prospectors are often acknowledged as firms with an intrapreneurial culture that encourages managers and employees to be more proactive and risk taking with respect to customer value delivery (Nasution \& Mavondo 2008). In addition, active entrepreneurs engage in a more aggressive orientation, and are willing to adopt high-risk actions (Avlonitis \& Salavou 2007). Hence, in terms of organizational expansion, active entrepreneurial firms are more likely to take risks, explore uncertainties, and venture into unfamiliar territories in search of new opportunities. Entrepreneurial firms demonstrate an active posture, and thus, a growing number of thesefirms enter foreign markets today, regardless of their origin.

Although much of the literature describes entrepreneurship orientation as a multidimensional construct comprising innovative, proactive, and riskseeking behaviors, these characteristics are not the only entrepreneurial dimensions that scholars have identified (Oviatt \& McDougall 2005). Nevertheless, previous conceptual and empirical research have found that innovative, proactive, and risk-seeking behaviors are positively related to internationalization intent (De Clercq, Sapienza \& Crijns 2005), international performance (Jantunen et al. 2008), and foreign profit and growth in revenue (Wiklund \& Shepherd 2005). As such, the present paper focuses on innovative, proactive, and risk-seeking dimensions.

In the context of international business, topics in entrepreneurship orientation are synonymous with enquiries into the emerging phenomena of SMEs internationalization. The international aspect of entrepreneurship is categorized under the research 
domains of entrepreneurship and international business studies. International entrepreneurship draws on a diverse range of theories based on various disciplines, such as international business, entrepreneurship, economics, psychology, finance, and marketing (McDougall \& Oviatt 2000). The multi-disciplinary nature of this topic notwithstanding, research into this area tends to converge on small businesses. We believe that this phenomenon can be explained by the external environment where, in competitive global markets, firms are pushed to redefine their positions in the competitive environment, thus they must revise their competitive strategies. That is, firms must transform their organizational cultures into successful models (Gonzalez-Benito, Gonzalez-Benito \& MunozGallego 2009). Although all types of businesses are subject to this environmental force, smaller firms experience greater difficulties in adjusting due to their lack of financial and human resources. In this situation, managerial focus is constantly being challenged by pressure to find alternative sources for competitive advantage. More often than not, these resources are intangible.

The idea discussed above can be conceptually justified via the resource perspective. According to Barney (1991), the central perspective in the RBV explains that firms establish competitive advantage by leveraging unique resources that are exclusive to the firm, such as assets and capabilities. Barney, Wright, and Ketchen (2001) emphasize the particular relevance of RBV in several fields of study, including entrepreneurship and international business. Likewise, Knight and Cavusgil (2004) suggest that in the context of international business, an entrepreneurial firm largely depends on the intangible capabilities related to the organizational culture. In this regard, entrepreneurial ability is considered as the most important foundation of competitiveness and international strategic formulation. Firms with embedded entrepreneurial cultures and demonstrate this value in their operations can overcome inherent weaknesses (Knight \& Cavusgil 2004).

In general, research interest in entrepreneurship focuses on the consequences of this aspect of organizational culture on performance (Gonzalez-Benito et al. 2009). However, research on the impact of entrepreneurship orientation on performance produces contradictory results. Some studies report positive impacts of entrepreneurship orientation on performance (e.g. Jantunen et al. 2008). On the other hand, other studies, such as the work of Lee, Lee and Pennings (2001) find only weak evidence; Slater and Narver (2000) discover no relationship between the two constructs. Nevertheless, in previous studies, entrepreneurship dimensions are commonly used in aggregate measures (Stam \& Elfring 2008; Wiklund \& Shepherd 2005). Furthermore, Lumpkin and Dess (1996) believe that the connection between entrepreneurship and performance is dependent on the context. In this regard, this study breaks from previous studies by employing a new perspective in investigating the effect of each dimension on the export performance of SMEs in emerging markets. Figure 1 shows the conceptual model illustrating the relationships between constructs.At best, our attempt provides insight on the interaction between entrepreneurship and performance by focusing on the individual role of each entrepreneurial dimension.

\section{PRO-ACTIVENESS AND EXPORT PERFORMANCE}

Pro-activenessrefers to the "...processes aimed at anticipating and acting on future needs by seeking new opportunities" (Lumpkin \& Dess 1996: 146). Similarly, pro-activeness also refers to the propensity to respond to expected changes in the environment (Lee et al. 2001).In a study by Avlonitis and Salavou (2007), pro-activeness is found to significantly affect the performance of new products significantly, which may include selling existing products in a new market. This definition is consistent with Lee et al. (2001), who assert that pro-activeness compels firms to form innovative methods and techniques, as well as pioneer new products. In a similar vein, Zahra and Garvis (2000) posit that entrepreneurship orientation drives firms to identify new operating modes and methods to help obtain new resources, thus enhancing performance. Additionally, they emphasize entrepreneurial activities as an antecedent to performance in general, and the success of international ventures in particular, given that entrepreneurship orientation provides the opportunity to conduct exploitation in the quest for expansion in new markets. Therefore, we believe that in anticipating the challenges of foreign markets, pro-active SMEs becoming international have the ability to find and exploit opportunities to their advantage. Accordingly, this study proposes the following hypothesis:

$\mathrm{H}_{1}$ Pro-activeness is positively related to export performance.

\section{RISK-TAKING AND EXPORT PERFORMANCE}

Risk-taking denotes the willingness to commit resources for unknown outcomes. Risk-taking involves two important elements: first, the company is willing to secede from the 'tried-and true,' and second, the company is ready to venture into the unknown (Wiklund \& Shepherd 2005). Lumpkin and Dess (1996) explain that firms with the propensity to take risks are more willing to invest in projects that carry uncertain outcomes, which may either generate high profits or great losses. The logic lies on the notion that any business risk that affects all firms is regarded as a general risk. Therefore, those firms that have the capacity to take projects with higher risks will have the tendency to provide better performance (Casillas \& Moreno 2010). Venturing into foreign markets demonstrates the willingness of the SMEs that have scarce resourcesto undertake high-risk activities. Thus, these firms are better prepared, and tend to reap a greater reward.This study recommends the following hypothesis: 
$\mathrm{H}_{2}$ Risk-taking is positively related to export performance.

\section{INNOVATIVENESS AND EXPORT PERFORMANCE}

The underlying provision of entrepreneurial orientation is innovativeness (Avlonitis \& Salavou 2007). Lumpkin and Dess (1996: 142) refer to innovativeness as “.... firm's tendency to engage in and support new ideas, novelty experimentation, and creative processes that may result in new products, services, or technological processes." Adding to Lumpkin and Dess (1996), Frishammar and Horte (2007) suggest that innovativeness is similar to culture. Innovative culture aids in developing key capabilities such as knowledge, and engenders the opening of new markets including international markets, the development of new methods for doing business (Knight \& Cavusgil 2004), and the creation of new products (Avlonitis \& Salavou 2007). This observation is similar to the view that innovation is an important factor in SMES internationalization, where innovativeness intensify the activities of firms in existing foreign markets, or increase the firms potential to enter new foreign markets as a means to leverage its ability (De Clercq et al. 2005). Hence, innovative strategy is significantly related to the growth rate of the firm (Moreno \& Casillas 2008). Knight and Cavusgil's (2004) investigation finds that entrepreneurship orientation may be particularly important to small internationalizing firms, as it appears to motivate them to develop high-quality goods that are distinctive and technologically advanced. In line with the above discussion, this study offers the following hypothesis:

$\mathrm{H}_{3}$ Innovativeness is positively related to export performance.

\section{METHODOLOGY}

\section{UNIT OF ANALYSIS AND KEY INFORMANT}

The unit of analysis refers to the level of investigation upon which the study focuses (Malhotra 2007). This study considers the specific SME manufacturer. In line with other studies (e.g., Matanda \& Freeman 2009), a single export venture has been chosen as the unit of analysis. Respondents were asked questions regarding their most successful and profitable export ventures that met the objectives set by the firm.
As the most common method employed by organizational researchers (Kumar, Stern \& Anderson 1993), the single-key informant approach is adopted in this study. The key informant was a senior executive of the firm, such as the chief executive officer/president, managing director, export manager, marketing/ sales manager, or officers that are directly involved in the management of export activities in the particular SME. The informants were selected based on two criteria.First, informants must be capable of understanding the concepts being measured, and willing and able to communicate the needed information (Kumar, Scheer \& Steenkamp 1995). Second, the individuals have substantial knowledge and experience in specific activities in the firm, such as exporting. These criteria are important to ensure that errors resulting from single key-informant are minimized (Sengun \& Wasti 2011; Zaheer, McEvily \& Perrone 1998).

As in this study, a single-key informant is susceptible to common method variance (CMV) (Lindell \& Whitney 2001), which is "...the amount of spurious covariance shared among variables because of the common method used in collecting data" (Malhotra, Kim \& Patil 2006: $1865)$. The test for CMV was performed following Lindell and Whitney (2001). An indicator based on the lowest correlation (positive) value was identified in Table 2. Based on the total number of uncorrected significant correlation, we found that inflation correlation due to CMV does not threaten the validity of the measures in the present study.

\section{SAMPLING}

The sampling frame consisted of cross-industry small and medium-sized Malaysian manufacturers currently engaged in export activity. The adoption of multi-industry sampling was aimed to increase the observed variance and strengthen the generalizability of the findings (Lages et al. 2009). Samples were identified from the major database the Federation of Malaysian Manufacturers (FMM). The industry of the manufacturers was categorized based on FMM criteria. In this study, the food and beverage industry comprises the greatest percentage, with 42 percent of the total respondents. This industry is followed by the chemical and petrochemical, wood and wood product, rubber product, and plastic product industries, with each representing 8 percent of the total respondents. On the other hand, the transport equipment industry comprises the smallest number, with 1 percent of the respondents. Textile, apparel and leather, and the paper and printing

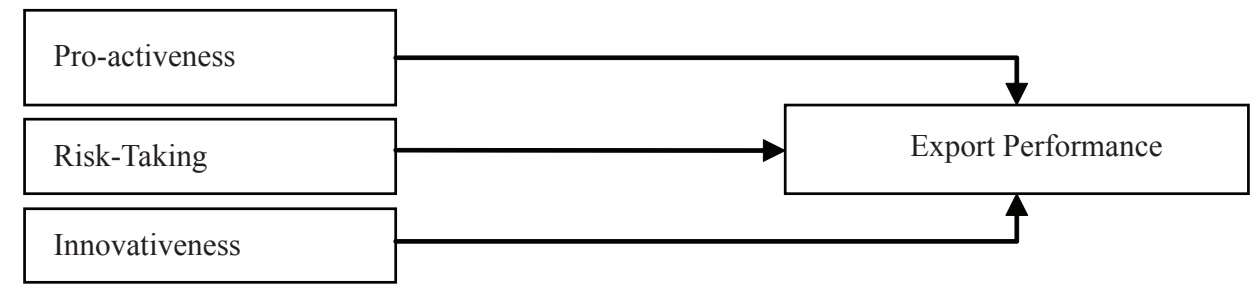

FIGURE 1. Conceptual model 
industries comprise 4 percent of the total respondents (refer to Table 1 for details).

Several criteria were set in choosing the firms for the study. First, the firms must be current exporters, with no minimum specification on the ratio of export sales to total production. Unlike certain scholars who suggest a minimum cut-off (e.g. Knight \& Cavusgil 2004; Zahra \& Garvis 2000), this study maintains that excluding a cut-off would allow various degrees of a firm's internationalization to be identified. Second, following Bell, Crick and Young (2004), the firm should be independent and indigenous (that is, not a subsidiary of a larger domestic or international company, to avoid potential resource and cultural influences on decisionmaking). Third, a minimum cut-off of 20 is required for the number of employees to capture an appropriate measure of constructs. This number is consistent with other studies (Kuivalainen, Sundqvist \& Servais 2007; Lumpkin \& Dess 1996; Marino et al. 2008), who suggest a minimum cut-off in the number of employees to guarantee that the respondent is a key informant, and to avoid firms without strategic commitment to cross border operations. Likewise, the limit of 250 was chosen for the same reason as for the minimum cut-off number of employees. In addition, many studies (e.g. Crick 2007; Majocchi, Bacchiocchi \& Mayrhofer 2005) limit the definition of SMEs as firms with up to 250 employees; hence, comparability of the results can be maintained.

For the purpose of data collection, and to ensure a higher response rate, a combination of methods was applied: drop-off for firms located close to the research stations, mail survey to cover distant locations, and employing the services of a local research company. The majority of the data was obtained via mail survey. Respondents were notified about the forthcoming survey prior to the mailing of the questionnaire. This notification was made through telephone calls and email to obtain a better response rate (Sekaran 2003). Subsequently, the questionnaire was sent, anda follow-up reminder was sent one week after the first letter. A follow-up mail questionnaire was sent four weeks after the first mail. For the drop-off survey, the respondent firms received a follow-up call. The researcher personally collected the questionnaire. The different methods of data collection - post, personal delivery, and research agency - were compared, and no significant differences were found.

Based on the FMM directory of FMM, only 851 firms met the criteria for this study. Of this number, 76 firms refused to participate, were not reachable, or had closed down. Finally, a total of 220 firms participated in the survey, constituting 28.38 percent $(220 / 783)$ as the effective response rate. Table 1 provides the details of the sample results.

\section{SURVEY INSTRUMENT}

The developed constructs were operationalized using existing scales identified in the literature. Some scales were retained in the iroriginal form, whereas others were modified and rephrased to suit the purpose and the context of the present study. In line with the procedures suggested by Churchill (1979) for the development of multi-item measures, in-depth interviews with selected SMEs and academics were conducted, and thus, items were refined. Details of all the measurements used in the present study are shown in Table 2.

For the aspect of entrepreneurship orientation, this study used items developed by Knight and Cavusgil (2004), Nasution and Mavondo (2008), Zhou (2007), Wang (2008), and Covin and Slevin (1989), which comprises three constructs, namely, pro-activeness, risktaking, and innovativeness. This scale has been extensively used in previous studies, suggesting the viability of this instrument for entrepreneurship orientation. Whereas both pro-activeness and innovativeness were measured using six items, risk-taking was measured using a five-

TABLE 1. Characteristics of the sample

\begin{tabular}{lclc}
\hline Firm Size (number of employee) & Percentage & Firm by Ownership (Ethnicity) & Percentage \\
\hline Small & 54.19 & Malay & 57.66 \\
Medium & 45.81 & Chinese & 30.63 \\
& & Others & Percentage \\
Key informant & Percentage & Industry of the respondent & 42 \\
Chief executive Officer/President & 8.6 & Food and beverage & 8 \\
Managing director & 27.6 & Wood and wood products & 8 \\
Export manager & 6.33 & Chemical and petrochemical & 8 \\
Marketing/sales manager & 24.43 & Rubber products & 8 \\
Others & 33.03 & Plastic products & 7 \\
& & Machinery and engineering & 7 \\
& & Electric and electronic & 4 \\
& & Pharmaceutical & 3 \\
& & Palm oil based products & 2 \\
& & Paper and printing & 2 \\
\end{tabular}


item scale. The respondents were asked as to what extent their firm performed each of the entrepreneurial practices depicted in each item. The scale used was the 7-point Likert scale, with a range of 1 as "not at all" to 7 as "to a great extent".

The subjective measure was used in this study to capture export performance. Thus, the five items were revised and adapted from Katsikeas, Leonidaou and Morgan (2000) and Shoham (1998). The respondents were asked as to what extent they have been satisfied with the statements in the items about the firm's export performance. The scales used were the 7-point Likert scale, with a range of 1 as 'strongly dissatisfied' to 7 as 'strongly satisfied.'

\section{VALIDITY AND RELIABILITY}

The measures of constructs were evaluated according to the paradigm proposed by Churchill (1979). To increase validity and reliability, the measurement scale was initially purified and examined for its dimensionality and internal consistency. As suggested by Ruekert and Churchill (1984), the correlation of item-to-total score of each dimension was calculated. Items without statistically significant higher correlation to the dimension were eliminated.

To control unidimensionality, the present study draws on previous studies (e.g. Nes, Solberg \& Silkoset 2007) in using confirmatory factor analysis (CFA) with maximum likelihood extraction. Thus, the measurement model (that is, innovativeness) was tested. The most common assessment tools for CFA are goodness-of-fit indexes.

To assess the constructs' validity, we use structural equation modeling using the Analysis of Moment Structures (Casillas et al. 2009) and the maximum likelihood estimation procedure. The results for the measurement models for all constructs are presented in Table 2. All standardized factor loadings range from 0.66 to 0.98 (all t-values greater than 8 ), well above the minimum level of 0.50 for convergence validity. The

TABLE 2. Confirmatory factor analysis

\begin{tabular}{|c|c|c|c|}
\hline Construct and source & Operational measures of construct & SFL & t-Value \\
\hline $\begin{array}{l}\text { Pro-active }^{\mathrm{a}} \\
\text { (Zhou 2007; Covin }\end{array}$ & $\begin{array}{l}\text { Model fit indexes: } x^{2}=2.241 ; d f=1 ; R M S E A=.075 ; G F I=.995 ; A G F I=.949 ; T L I \\
=.984: N F I=0.995 ; C F I=.997\end{array}$ & & \\
\hline \& Slevin 1989; & i. We actively seek contact with clients in international markets & 0.84 & 11.43 \\
\hline \multirow[t]{5}{*}{ Jantunen et al. 2008) } & ii. We regularly monitor the trend of export markets & 0.80 & 10.06 \\
\hline & iii. We actively explore business opportunities abroad & 0.86 & 11.64 \\
\hline & $\begin{array}{l}\text { iv. We constantly seek opportunities to improve our business } \\
\text { performance }\end{array}$ & 0.72 & - \\
\hline & v. We are always ahead of our competitor in responding to market challenges* & & \\
\hline & vi. We actively adopt the best practices in our sector* & & \\
\hline $\begin{array}{l}\text { Risk-taking }^{\text {a }} \\
\text { (Nasution \& }\end{array}$ & $\begin{array}{l}\text { Model fit indexes: } x^{2}=1.876 ; d f=2 ; R M S E A=.000 ; G F I=.996 ; A G F I=.978 ; \\
T L I=1.001 N F I=0.993 ; C F I=1.000\end{array}$ & & \\
\hline \multirow[t]{5}{*}{ Mavondo 2008) } & i. In this organization uncertainty is treated as a challenge & 0.66 & 8.65 \\
\hline & ii. Employees are encouraged to venture into unexplored territories & 0.76 & 9.58 \\
\hline & iii. Management accept that certain suggestions may fail when implemented & 0.72 & 9.27 \\
\hline & iv. Our firm emphasises opportunity for success rather than chances for failure* & & \\
\hline & v. In this organization new venture failure is viewed as a learning experience & 0.75 & - \\
\hline $\begin{array}{l}\text { Innovative }^{\text {a }} \\
\text { (Zhou 2007; Wang }\end{array}$ & $\begin{array}{l}\text { Model fit indexes: } x^{2}=10.444 ; d f=7 ; \text { RMSEA }=.047 ; G F I=.985 ; A G F I=.956 ; \\
T L I=.990 ; N F I=0.987 ; C F I=0.995\end{array}$ & & \\
\hline \multirow[t]{6}{*}{ 2008) } & i. We are open to innovative ways of exploiting international market opportunities & 0.81 & 13.16 \\
\hline & ii. We continuously search for new export markets & 0.71 & 11.17 \\
\hline & iii. We actively adopt "new ways of doing things" by main competitors & 0.78 & 12.48 \\
\hline & iv. We are willing to invest in new ways of doing business & 0.77 & 12.43 \\
\hline & v. We encourage our people to think and behave in novel ways & 0.66 & 12.68 \\
\hline & vi. We value creative new solutions & 0.82 & - \\
\hline $\begin{array}{l}\text { Export Performance } \\
\text { (Katsikeas et al. }\end{array}$ & $\begin{array}{l}\text { Model fit indexes: } x^{2}=2.434 ; d f=2 ; \text { RMSEA }=.031 ; G F I=.996 ; A G F I=.967 ; \\
T L I=.999 ; N F I=0.998 ; C F I=1.000\end{array}$ & & \\
\hline \multirow[t]{5}{*}{ 2000; Shoham 1998) } & i. Percentage of export volume to total sale volume (quantity) & 0.93 & 20.40 \\
\hline & ii. Percentage of export revenue to total sales revenue & 0.98 & 22.43 \\
\hline & iii. Contribution of export profit to total profits & 0.91 & 23.93 \\
\hline & iv. Growth rate of export sales & 0.82 & 29.66 \\
\hline & v. Overall export performance & 0.86 & - \\
\hline
\end{tabular}

Notes: $(*)$ Item deleted during the scale purification process

$(-)$ Measurement item fixed for estimation.

$\mathrm{SFL}=$ standardized factor loadings.

a Measures on 7-point Likert scale anchored on $1=$ "not at all"; $7=$ "to a great extent".

${ }^{b}$ Measures on 7-point Likert scale anchored on 1 = "strongly dissatisfy"; 7 = "strongly satisfy". 
fit indexes show that the models met the requirements of acceptable fit, and thus confirmed the existence of convergence validity.

Discriminant validity pertains to demonstrating whether a construct can be differentiated from other constructs (Nes et al. 2007). Fornell and Larcker (1981) suggest the use of average variance extracted (AVE). As shown in Table 3, an AVE score higher than the correlation between two constructs proves the discriminant validity. In addition, following Atuahene-Gima (2005), a series of confirmatory factor analyses were also conducted to test whether a two-factor model of these measures would match well again a one-factor model, a method put forward by Bagozzi, Yi and Philips (1991). A chi square $\left(x^{2}\right)$ difference greater than $3.84(\mathrm{p}<0.05)$ indicates that the two constructs are dissimilar. Results in Table 4 showthat in all cases, the chi-square for the constrained model was significantly larger than the chi-square for the unconstrained model, thus confirming the discriminant validity further.

Using the procedure proposed by Fornell and Larcker (1981), the composite reliability was calculated to find evidence of the internal consistency of the scale. The coefficient of the constructs (see Table 3 ) ranged from 0.83 to 0.98 , which was well above the acceptable standard (Fornell \& Larcker 1981; Nunnally 1978).

\section{DATA ANALYSIS}

The research model was estimated using the structural equation modeling technique. Table 5 provides the results of the tests that assess the hypothesized relationship. The data were analyzed in AMOS16. Scores for model fit indexes indicate acceptable fit measures $\left(x^{2}=168.608 ; \mathrm{df}=71 ; \mathrm{RMSEA}=0.08 ; \mathrm{TLI}=.93 ; \mathrm{NFI}\right.$ $=.91 ; \mathrm{CFI}=.95)$.

The results provide strong evidence that proactiveness is a significant function of export performance, supporting hypothesis H1. However, the posited relationship between risk-taking and export performance was not significant, and thus, hypothesis $\mathrm{H} 2$ is not supported. Findings also reveal that innovativeness is significantly related to export performance. Hence, hypothesis $\mathrm{H} 3$ is supported.

TABLE 3. Average Variance Extracted (AVE) and correlations of constructs

\begin{tabular}{lcccc}
\hline Construct & 1 & 2 & 3 & 4 \\
\hline 1. Pro-activeness & .80 & & & \\
2. Risk-taking & $.50^{* * *}$ & .72 & & \\
3. Innovativeness & $.54^{* * *}$ & $.68^{* * *}$ & .75 & .90 \\
4. Export Performance & $.38^{* * *}$ & $.32^{* * *}$ & $.27^{* * *}$ & .98 \\
\hline Internal consistency & .88 & .83 & .89 & 4.73 \\
Mean & 5.33 & 5.10 & 5.24 & 1.30 \\
Standard deviation & 1.03 & .98 & 1.08 & -.69 \\
Skewness & -.88 & -.52 & -.85 & -.10 \\
Kutosis & 1.37 & .37 & 1.08 & \\
\hline
\end{tabular}

Notes: $* *$ Correlation is significant at the 0.001 level (1-tailed); $* *$ Correlation is significant at the 0.01 level (1-tailed); $*$ Correlation is significant at the 0.05 level (1-tailed). Average Variance Extracted (AVE) value is shown in diagonal; Cronbach Alpha value is shown in the row of $\alpha$.

TABLE 4. Test of Chi-square different for covariance parameter constrained unconstrained chi-square

\begin{tabular}{|c|c|c|c|c|c|c|}
\hline \multirow[t]{2}{*}{ Covariance } & \multirow[t]{2}{*}{ Parameter } & \multicolumn{2}{|c|}{ Constrained } & \multicolumn{2}{|c|}{ Unconstrained } & \multirow{2}{*}{$\begin{array}{l}\text { Chi-square } \\
\text { difference }\end{array}$} \\
\hline & & CMIN & Df & CMIN & df & \\
\hline Pro-activeness - Risk-taking & 1 & 73.34 & 18 & 39.49 & 17 & $33.85 * * *$ \\
\hline Pro-activeness - Innovativeness & 1 & 137.44 & 33 & 112.94 & 32 & $24.49 * * *$ \\
\hline Pro-activeness - Export Performance & 1 & 97.96 & 24 & 57.53 & 23 & $40.42 * * *$ \\
\hline Risk-taking - Innovativeness & 1 & 84.43 & 33 & 76.53 & 32 & $7.90 * *$ \\
\hline Risk-taking - Export Performance & 1 & 64.21 & 25 & 40.59 & 24 & $23.62 * * *$ \\
\hline Innovativeness - Export Performance & 1 & 217.46 & 42 & 201.61 & 41 & $15.84 * * *$ \\
\hline
\end{tabular}

Note: $* * *$ significant at $\mathrm{p}<.001 ; * *$ significant at $\mathrm{p}<.01 ; *$ significant at $\mathrm{p}<.05$

TABLE 5. Results of analyses on hypothesized relationships

\begin{tabular}{lccc}
\hline Hypothesized relationship & $\mathrm{B}$ & t-value & Hypotheses \\
\hline Pro-activeness $\rightarrow$ Export Performance & 0.67 & $3.64 * * *$ & H1 - Supported \\
Risk-taking $\rightarrow$ Export Performance & -0.19 & -1.11 & H2 - Not Supported \\
Innovativeness $\rightarrow$ Export Performance & 0.46 & $2.21 *$ & H3 - Supported \\
\hline Note $* \mathrm{p}<.05 ; * * \mathrm{p}<.01 ; * * * \mathrm{p}<.001$ & & &
\end{tabular}




\section{DISCUSSION AND CONCLUSION}

The growing competition in the domestic market and the diminishing trade barriers has led firms to venture into cross-border markets to meet corporate objectives. The enhanced ability of SMEs to compete in international markets successfully despite its scarcity in resource has become the focus of many studies. Extant literature has acknowledged the importance of firm-specific factors (e.g. Jantunen et al. 2008; Knight \& Cavusgil 2004; Roxas \& Chadee 2011). However, studies in the context of emerging marketsare rare, explaining the limited understanding of small business international markets venture (Filatotchev et al. 2009). As such, this study proposes an exceptional contribution in the existing literature.

This study has sought to address the existing gap in literature by focusing on the entrepreneurial capability of firms. Thus, we build the conceptual framework based on the RBV, and propose the organization capability posture to analyze the performance outcome of SMEs in export markets. Past studies have found evidence of the influence of entrepreneurship on export performance. Nevertheless, this study further investigates this relationship by focusing on the performance effect of each dimensions of entrepreneurship orientation. Consequently, this study extends the RBV in the context of emerging market exporters, and acknowledges the individual role of entrepreneurship dimensions on the performance of SMEs in emerging markets.

The findings show the significant consequential effect ofpro-activeness and innovativeness on export performance. In particular, the findings suggest that proactiveness has an important effect on the performance of small business export ventures. This result affirms the notion that entrepreneurship orientation is about a pro-active strategic orientation (Foxall 1984), which is consistent to the view that international business venture involves opportunity-seeking behavior. Therefore, being pro-active enables firms to meet emerging and unarticulated customer needs, which is required to counter the autocracy of the market and to direct the customer(Atuahene-Gima $\&$ Ko 2001). That is, pro-activeness facilitates ideas that will transform the competitive landscape to the firm's advantage.

Entrepreneurship orientation compels firms to be more successful in very dynamic environments, as a result of innovative posture. In this light, Knight and Cavusgil (2004) assert that entering a foreign market is an innovative action which compels firms to developnew ways of doing business in a new environment. This finding supports the report by Atuahene-Gima and Ko (2001), who find that entrepreneurial-oriented firms appear to place more significance to innovation in their practices. Hence, the significant effect of innovativeness on export performance is not surprising.
Based on the results, risk-taking is found to have no significant effect on export performance. Seemingly, this finding is due to the context-dependency of the relationship between entrepreneurship and performance. The relationship appears stronger in environments which have the following characteristics: highly intense competitive atmosphere, a lack of readily exploitable market opportunities, great competitiveness, uncertainties related to market and product, and general vulnerability to the influence of factors that are outside the control of the firm (Gonzalez-Benito et al. 2009). In the present study, most firms are producers of commodity-based products, hence the more stable environment. Therefore, the managers in this study do not feel that taking greater risk in cross border ventures will contribute to better export performance.

Although the sample of this study includes Malaysian SMEs, the findings, like other studies (e.g., Lu et al. 2010; Zhou, Wu \& Luo 2007), are believed to be applicable to SMEs in other emerging markets. In particular, the respondents in our sample believe in the significance of the effect of pro-activeness and innovativeness on export performance. This finding suggests that in the dynamic environment of international markets, SMEs in emerging markets should focus on developing a proactive and innovative posture to build their capability, and consequently, to compete successfully and achieve greater performance in export markets. Conversely, compared to pro-activeness and innovativeness, the effect of risk-taking on performance is less noteworthy. The risk-taking dimension is perceived to be the cost associated with the international business (Zhou 2007), hence, in a stable environment, no positive contribution to the performance of SMEs can be expected. Nevertheless, the managers of SMEs may have to engage in risktaking activities when the environment is characterized by the entrenched posture of greater uncertainty and complexity.

In the case of emerging markets, developing the ability of SMEs to compete in international markets heavily relies on governmental support. Therefore, policymakers should encourage SMEs to be more proactive and innovative by organizing trade fare that allows the domestic SMEs to interact and coordinate with foreign organizations, such as businesses and research institutions. In addition, the government can also provide training for SME managers. These measures will help SMEs to understand the complexity of international business.

Finally, the findings suggest that researchers should carefully scrutinize the dimensions of entrepreneurship orientation, and treat these dimensions separately, as each of the dimensions has a distinct effect on the performance of SMEs in an export market. In this case, aggregating the dimensions into a single construct could potentially alter the results. 


\section{LIMITATIONS AND IMPLICATION ON FUTURE STUDY}

The present study has several limitations. First, the sample was derived from the manufacturing sector, and thus, generalization is less likely to be applied to other industries, such as the service sector. This suggests that existing studies can be extended to the service sector in future research work.

The second limitation is the respondents' ethnic background. In the context of Malaysia, the greatest participants in the domestic economy belong to the Chinese ethnic group. Hence, the majority of small and medium manufacturing exporters are owned by them. However, in this study, more than half (58 percent of the respondents were Malay, and the Chinese comprised only 31 percent of the total respondents). The sample was therefore biased towards the Malay businesses.

Finally, further research should address the following suggestions:based on the literature, this study adopts subjective measures for export performance. To ensure the measure variability and the rigor of the findings, future studies may consider financial measures, although these means may be difficult for small business research. Finally, although the test for common method variance suggests that single-key informants are appropriate for this study, future researchers can adopt different approaches to obtain various responses. One approach could be the use of multiple respondents, which can minimize the problem of single-key informants.

\section{REFERENCES}

Ali Ulubasoglu, M., Akdis, M. \& Kok S. B. 2009. Internationalization and alliance formation: Evidence from Turkish SMEs. International Small Business Journal 27(3): 337-361.

Atuahene-Gima, K. 2005. Resolving the capability-rigidity paradox in new product innovation. Journal of Marketing 69: 61-83.

Atuahene-Gima, K. \& Ko, A. 2001. An empirical investigation of the effect of market orientation and entrepreneurship orientation alignment on product innovation. Organization Science 12(1): 54-74.

Avlonitis, G. J. \& Salavou, H. E. 2007. Entrepreneurial orientation of SMEs, product innovativeness, and performance. Journal of Business Research 60(5): 566-575.

Bagozzi, R. R., Yi, Y. \& Phillips, L. W. 1991. Assessing construct validity in organizational research. Administrative Science Quarterly 36: 421-458.

Barney, J. B. 1991. Firm resources and sustained competitive advantage. Journal of Management 17(1): 99-120.

Barney, J. B., Wright, M. \& Ketchen, D. J. 2001. The resourcebased view of the firm: Ten years after 1991. Journal of Management 27(6): 625-641.

Bell, J., Crick, D. \& Young, S. 2004. Small firm internationalization and business strategy: An exploratory study of knowledgeintensive and traditional manufacturing firms in the U.K. International Small Business Journal 22(1): 23-56.

Buckley, M. R., Cote, J. A. \& Comstoct, S. M. 1990. Measurement errors in behavioral sciences: The case of personality/ attitude research. Educational Psych. Measurement 50(3): 447-474.

Casillas, J. C. \& Moreno, A. M. 2010. The relationship between entrepreneurial orientation and growth: The moderating role of family involvement. Entrepreneurship and Regional Development 22(3-4): 265-291.

Casillas, J. C., Moreno, A. M., Acedo, F. J., Gallego, M. A. \& Ramos, E. 2009. An integrative model of the role of knowledge in the internationalization process. Journal of World Business 44(3): 311-322.

Che Senik, Z., Mohamed Makhbul, Z. K., Yusof, R., Mat Isa, R. \& Md Sham, R. 2012. Proses pengantarabangsaan Enterpris Kecil dan Sederhana (EKS): Mengenal pasti dimensi melalui teknik Delphi. Jurnal Pengurusan 34: 123-136.

Churchill, G. A. 1979. A paradigm for developing better measures of marketing constructs. Journal of Marketing Research 16(1): 64-73.

Covin, J. G. \& Slevin, D. P. 1989. Strategic management of small firms in hostile and benign environments. Strategic Management Journal 10(1): 75-87.

Crick, D. 2007. UK SMEs' motives for internationalizing: Differences between firms employing particular overseas market sevicing strategies. Journal of International Entrepreneurship 5(1-2): 11-23.

De Clercq, D., Sapienza, H. J. \& Crijns, H. 2005. The internationalization of small and medium-sized firms. Small Business Economics 24(4): 409-419.

Filatotchev, I., Liu, X. H., Buck, T. \& Wright, M. 2009. The export orientation and export performance of hightechnology SMEs in emerging markets: The effects of knowledge transfer by returnee entrepreneurs. Journal of International Business Studies 40(6): 1005-1021.

Fornell, C. \& Larcker, D. F. 1981. Evaluating Structural equation models with unobservable variables and measurement error. Journal of Marketing Research 18(1): 39-50.

Foxall, G. R. 1984. Corporate Innovation: Marketing and Strategy. Beckenham, Kent, UK: Croom Helm.

Frishammar, J. \& Horte, S. A. 2007. The role of market orientation and entrepreneurial orientation for new product development performance in manufacturing firms. Technology Analysis \& Strategic Management 19: 765-788.

Gonzalez-Benito, O., Gonzalez-Benito, J. \& Munoz-Gallego, P. A. 2009. Role of entrepreneurship and market orientation in firm's success. European Journal of Marketing 43(3/4): 500-522.

Higon, D. A. \& Driffield, N. 2011. Exporting and innovation performance: Analysis of the annual Small Business Survey in the UK. International Small Business Journal 29(1): 4-24.

Jantunen, A., Nummela, N., Puumalainen, K. \& Saarenketo, S. 2008. Strategic orientations of born globals - Do they really matter? Journal of World Business 43(2): 158-170.

Katsikeas, C. S., Leonidou, L. C. \& Morgan, N. A. 2000. Firmlevel export performance assessment: Review, evaluation, and development. Journal of the Academy of Marketing Science 28(4): 493-511.

Knight, G. A. \& Cavusgil, S. T. 2004. Innovation, organizational capabilities, and the born-global firm. Journal of International Business Studies 35: 124-141.

Kuivalainen, O., Sundqvist, S. \& Servais, P. 2007. Firms' degree of born-globalness, international entrepreneurial orientation and export performance. Journal of World Business 42(3): 253-267. 
Kumar, N., Scheer, L. K. \& Steenkamp, J. B. E. M. 1995. The effects of perceived interdependence on dealer attitudes. Journal of Marketing Research 32(3): 348-356.

Kumar, N., Stern, L. W. \& Anderson, J. C. 1993. Conducting Interorganizational Research Using Key informants Academy of Management Journal 36(6): 1633-1651.

Lages, L. F., Silva, G., Styles, C. \& Pereira, Z. L. 2009. The NEP Scale: A measure of network export performance. International Business Review 18: 344-356.

Lee, C., Lee, K. \& Pennings, J. M. 2001. Internal capabilities, external networks, and performance: A study on technologybased venture. Strategic Management Journal 22(6-7): 615-640.

Lindell, M. K. \& Whitney, D. J. 2001. Accounting for common method variance in cross-sectional research designs. Journal of Applied Psychology 86(1): 114-121.

Lu, Y., Zhou, L., Bruton, G. \& Li, W. 2010. Capabilities as a mediator linking resources and the international performance of entrepreneurial firms in an emerging economy. Journal of International Business Studies 41: 419-436.

Lumpkin, G. T., Cogliser, C. C. \& Schneider, D. R. 2009. Understanding and measuring autonomy: An entrepreneurial orientation perspective. Entrepreneurship Theory and Practice 33(1): 47-69.

Lumpkin, G. T. \& Dess, G. G. 1996. Clarifying the entrepreneurial orientation construct and linking it to performance. Academy of Management Review 21(1): 135-172.

Majocchi, A., Bacchiocchi, E. \& Mayrhofer, U. 2005. Firm size, business experience and export intensity in SMEs: A longitudinal approach to complex relationships. International Business Review 14(6): 719-738.

Malhotra, N. K. 2007. Marketing Research: An Applied Orientation. $5^{\text {th }}$ edition. Upper Saddle River, NJ: Pearson Prentice Hall.

Malhotra, N. K., Kim, S. S. \& Patil, A. 2006. Common method variance in IS research: A comparison of alternative approaches and a reanalysis of past research. Management Science 52(12): 1865-1883.

Marino, L. D., Lohrke, F. T., Hill, J. S., Weaver, K. M. \& Tambunan, T. 2008. Environmental shocks and SME alliance formation intentions in emerging economy: Evidence from the Asian financial crisis in Indonesia Entrepreneurship Theory and Practice 32(1): 157-183.

Matanda, M. J. \& Freeman, S. 2009. Effect of perceived environmental uncertainty on exporter-importer interorganisational relationships and export performance improvement. International Business Review 18(1): 89107.

McDougall, P. P. \& Oviatt, B. M. 2000. International entrepreneurship: The intersection of two research paths. Academy of Management Journal 43(5): 902-906.

Miller, D. 1983. The correlates of entrepreneurship in three types of firms. Management Science 29(7): 770-791.

Moreno, A. M. \& Casillas, J. C. 2008. Entrepreneurship orientation and growth of SMEs: A causal model. Entrepreneurship Theory and Practice 32(3): 507-528.

Nasution, H. N. \& Mavondo, F. T. 2008. Organisational capabilities: antecedents and implications for customer value. European Journal of Marketing 42(3/4): 477-501.

Nes, E. B., Solberg, C. A. \& Silkoset, R. 2007. The impact of national culture and communication on exporter-distributor relations and on export performance. International Business Review 16(4): 405-424.
Nunnally, J. C. 1978. Psychometric Theory. $2^{\text {nd }}$ edition. New York: McGraw Hill.

O'Cass, A. \& Weerawardena, J. 2009. Examining the role of international entrepreneurship, innovation and international market performance in SME internationalisation. European Journal of Marketing 43(11-12): 1325-1348.

Oviatt, B. M. \& McDougall, P. P. 2005. Defining international entrepreneurship and modeling the speed of internationalization. Entrepreneurship Theory and Practice 29(5): 537-553.

Roxas, H. B. \& Chadee, D. 2011. A resource-based view of small export firms' social capital in a Southeast Asian Country. Asian Academy of Management Journal 16(2): 1-28.

Ruekert, R. \& Churchill, G. 1984. Reliability and validity of alternative measures of channel member satisfaction. Journal of Marketing Research 21: 226-233.

Sekaran, U. 2003. Research method for business: A skill building approach. New York: Wiley.

Sengun, A. E. \& Wasti, S. N. 2011. Trust types, distrust, and performance outcomes in small business relationships: The pharmacy-drug warehouse case. Service Industries Journal 31(2): 287-309.

Shoham, A. 1998. Export performance: A conceptualization and empirical assessment. Journal of Marketing 6(3): 59-81.

Slater, S. F. \& Naver, J. C. 2000. The positive effect of a market orientation on business profitability: A balanced replication. Journal of Business Research 48(1): 69-73.

Stam, W. \& Elfring, T. 2008. Entrepreneurial orientation and new venture performance: The moderating role of intraand extra-industry social capital. Academy of Management Journal 51(1): 97-111.

Teece, D. J., Pisano, G. \& Shuen, A. 1997. Dynamic capabilities and strategic management. Strategic Management Journal 18(7): 509-533.

Wang, C. L. 2008. Entrepreneurial orientation, learning orientation, and firm performance. Entrepreneurship Theory and Practice 32(4): 635-657.

Wiklund, J. \& Shepherd, D. A. 2005. Entrepreneurial orientation and small business performance: A configurational approach. Journal of Business Venturing 20(1): 71-91.

Woldesenbet, K., Ram, M. \& Jones, T. 2012. Supplying large firms: The role of entrepreneurial and dynamic capabilities in small businesses. International Small Business Journal 30(5): 493-512.

Wright, M., Filatotchev, I. \& Hoskisson, R. E. 2005. Strategy research in emerging economies: Challenging the conventional wisdom. Journal of Management Studies 42(2): 1-33.

Zaheer, A., McEvily, B. \& Perrone, V. 1998. Does trust matter? Exploring the effects of interorganizational and interpersonal trust on performance. Organization Science 9(2): 141-159.

Zahra, S. A. \& Garvis, D. M. 2000. International corporate entrepreneurship and firm performance: The moderating effect of international environmental hostility. Journal of Business Venturing 15(5-6): 469-492.

Zhou, L. 2007. The effects of entrepreneurial proclivity and foreign market knowledge on early internationalization. Journal of World Business 42(3): 281-293.

Zhou, L., Wu, W. \& Luo, X. 2007. Internationalization and the performance of born-global SMEs: The mediating role of social networks. Journal of International Business Studies 38(4): 673-690. 
Md Daud Ismail (corresponding author)

Faculty of Economics and Management

Universiti Kebangsaan Malaysia

43600 UKM Bangi, Selangor

E-Mail:mddaud@ukm.my

\section{Azwardi Md Isa}

College of Laws, Government, and International Studies

Universiti Utara Malaysia

06010 UUM Sintok, Kedah

E-Mail: azwardi@uum.edu.my

Mohd Helmi Ali

Faculty of Economics and Management

Universiti Kebangsaan Malaysia

43600 UKM Bangi, Selangor

E-Mail: mohdhelmiali@ukm.my 
